\title{
Vitamin D, vitamin D binding protein, vitamin $D$ receptor levels and cardiac dysautonomia in patients with multiple sclerosis: a cross-sectional study
}

\author{
Vitamina $\mathrm{D}$, proteína de ligação à vitamina $\mathrm{D}$, níveis de receptores de vitamina $\mathrm{D}$ e \\ disautonomia cardíaca em pacientes com esclerose múltipla: um estudo transversal
} Tülin AKTÜRK' , Yașar TURAN', Nermin TANIK', Müjgan Ercan KARADAĞ², Hikmet SACMACI', Levent Ertugrul INAN ${ }^{1}$

\begin{abstract}
Vitamin $\mathrm{D}$ is a pleiotropic steroid hormone that modulates the autonomic balance. Its deficiency has been described as an environmental risk factor for multiple sclerosis (MS). The aim of this study was to investigate the serum levels of vitamin D, vitamin D binding protein (VDBP) and vitamin D receptors (VDR) and to evaluate cardiac dysautonomia in MS patients due to bidirectional interaction between vitamin D and the autonomic nervous system. Methods: The current cross-sectional study was conducted on 26 patients with relapsing-remitting MS and on 24 healthy controls. Twenty-four-hour ambulatory blood pressure variability (BPV) was calculated and the participants were evaluated for orthostatic hypotension and supine hypertension. Serum levels of vitamin D, VDBP and VDR were measured. Results: The mean serum vitamin D level was significantly lower in MS patients than in controls ( $p=0.044)$; however there was no significant difference in terms of VDR and VDBP levels between the groups. Supine hypertension and orthostatic hypotension were significant and the 24-hour systolic BPV was significantly decreased in patients with MS $(p<0.05)$ compared to controls. No correlation was found between vitamin D, VDBP and VDR with supine hypertension, orthostatic hypotension and systolic BPV values ( $p>0.05)$. Also, there was a negative correlation between VDBP and the EDSS ( $p=0.039, r=-0.406$ ). Conclusion: There was no correlation between orthostatic hypotension, supine hypertension and systolic BPV values and serum vitamin D, VDBP and VDR in MS patients. Future prospective studies with large number of patients may help us to better understand the relationship between vitamin $\mathrm{D}$ and the autonomic nervous system.
\end{abstract}

Keywords: Multiple sclerosis; vitamin D binding protein; receptors, calcitriol.

RESUMO

A vitamina D é um hormônio esteroide pleiotrópico que modula o equilíbrio autonômico. Sua deficiência tem sido descrita como fator de risco ambiental para esclerose múltipla (EM). 0 objetivo deste estudo foi investigar os níveis séricos de vitamina $\mathrm{D}$, proteína de ligação à vitamina $\mathrm{D}$ (VDBP) e receptor de vitamina D (VDR) e avaliar a disautonomia cardíaca em pacientes com EM devida à interação bidirecional entre vitamina D e sistema nervoso autônomo. Métodos: 0 presente estudo transversal foi realizado em 26 pacientes com EM remitente-recorrente e em 24 controles saudáveis. A variabilidade da pressão arterial ambulatorial (BPV) por 24 horas foi calculada e os participantes foram avaliados quanto à hipotensão ortostática e hipertensão supina. Os níveis séricos de vitamina D, VDBP e VDR foram medidos. Resultados: 0 nível sérico médio de vitamina D foi significativamente menor nos pacientes com EM do que nos controles ( $p=0,044)$; no entanto, não houve diferença significativa em termos de níveis de VDR e VDBP entre os grupos. Hipertensão supina e hipotensão ortostática foram significativas e a BPV sistólica de 24 horas diminuiu significativamente em pacientes com EM $(p<0,05)$ em comparação aos controles. Não foi encontrada correlação entre vitamina D, VDBP e VDR com hipertensão supina, hipotensão ortostática e BPV sistólica ( $p>0,05)$. Também houve correlação negativa entre VDBP e EDSS ( $p=0,039, r=-0,406)$. Conclusão: Não houve correlação entre hipotensão ortostática, hipertensão supina e valores de BPV sistólica e vitamina D sérica, VDBP e VDR em pacientes com EM. Futuros estudos prospectivos com grande número de pacientes podem nos ajudar a entender melhor a relação entre vitamina D e sistema nervoso autônomo.

Palavras-chave: Esclerose múltipla; proteína de ligação a vitamina D; receptores de calcitriol.

'Bozok University, Department of Cardiology, Yozgat, Turkey;

${ }^{2}$ Harran University, Department of Biochemistry, Sanliurfa, Turkey;

Tülin Aktürk (iD) https://orcid.org/0000-0003-1818-1578; YașarTuran (iD https://orcid.org/0000-0002-2796-899X; Nermin Tanık https://orcid.org/0000-0002-7567-9244; Müjgan Ercan Karadağ (iD https://orcid.org/0000-0002-9291-4197; Hikmet Sacmacı (iD) https://orcid.org/0000-0003-1480-0562; Levent Ertuğrul Inan (iD) https://orcid.org/0000-0002-2441-0624

Correspondence: Tülin Aktürk; Bozok University Department of Neurology Yozgat Yozgat 66200, Turkey; E-mail: tulin_birlik@hotmail.com

Conflict of interest: There is no conflict of interest to declare.

Received 08 July 2019; Received in final form 08 August 2019; Accepted 09 August 2019. 
Multiple sclerosis (MS) is the most common immunemediated inflammatory, demyelinating disease of the central nervous system, which primarily affects young adults. The exact cause of MS is unknown. The prevalence of vitamin D deficiency is high in patients with $\mathrm{MS}^{1}$. Circulating metabolites of vitamin $\mathrm{D}$ are transported by vitamin $\mathrm{D}$ binding protein (VDBP), and vitamin D shows its effects on the organism by binding to the intracellular vitamin $\mathrm{D}$ receptors (VDR). In addition to known effects of vitamin $\mathrm{D}$ on the skeletal system and calcium-phosphate homeostasis, discovery of the vitamin $\mathrm{D}$ receptor in the cells of the immune system, and that the dendritic cells produce the active form of vitamin $\mathrm{D}$ hormone, has suggested that vitamin D could have an immunomodulatory role ${ }^{2,3}$. Vitamin D is a lipid soluble hormone that modulates the autonomic balance and regulates the sympathetic and parasympathetic system ${ }^{4}$. It has been asserted that vitamin $\mathrm{D}$ deficiency has contributed to autonomic nervous system dysfunction ${ }^{5}$. We aimed to compare the serum levels of vitamin D, VDBP and VDR between MS patients and control groups and to evaluate cardiac autonomic dysfunction due to the interaction between vitamin $\mathrm{D}$ and the autonomic nervous system.

\section{METHODS}

\section{Study population}

Twenty-six patients with MS (in the remission phase), aged between 18 and 45, diagnosed according to the 2010 McDonald criteria ${ }^{6}$, who attended the Neurology outpatient clinic between December 2017 and February 2018, only in winter, between $36^{\circ}$ and $42^{\circ}$ of latitude, and 24 healthy controls were enrolled in this cross-sectional study. Inclusion criteria were as follows; a relapsing-remitting multiple sclerosis (RRMS) disease course, no relapse of MS within six weeks before blood sampling, using immunomodulatory drugs (interferon beta-1a, -1b and glatiramer acetate) or no treatment. Clinical and demographic characteristics of the patients were recorded. Body mass index was calculated $\left(\mathrm{kg} / \mathrm{m}^{2}\right)$. The severity of the disease was assessed using the Expanded Disability Status Scale (EDSS) score. Blood samples were collected from MS patients and from control participants in the same months. None of the patients had received vitamin $\mathrm{D}$ replacement in the previous three months.

The exclusion criteria were: diagnosis of any cardiac, thyroid or lung disease, alcohol dependence, connective tissue disease, hypertension, diabetes, renal failure, liver failure, acute or chronic infection, anemia, clinical sign of polyneuropathy, smoking, pregnancy and medications other than MS drugs.

This study was approved by the ethics committee (protocol number: 2017-KAEK-189_2017.10.03_12) and supported by the project coordination unit (6602a-TF/18-146) in our university. All the participants provided written informed consent.

\section{Cardiac data collection}

The examination room was maintained at a comfortable temperature of 23-26 degrees Celsius. An electrocardiogram was recorded for each participant. Blood pressure was measured using a calibrated sphygmomanometer with the patient in the sitting position for at least five minutes. In order to evaluate orthostatic hypotension, blood pressure was measured using a cuffed sphygmomanometer in the supine position and three minutes after standing up. Orthostatic hypotension was defined as a drop in systolic blood pressure of at least $20 \mathrm{mmHg}$ and/or diastolic blood pressure of at least $10 \mathrm{mmHg}$ within three minutes of standing up $\mathrm{up}^{7}$. The blood pressure of all participants was measured in the standing position and after five minutes in a supine position. Supine hypertension was defined as systolic blood pressure $\geq 140 \mathrm{mmHg}$ or diastolic blood pressure $\geq 90 \mathrm{mmHg}$ after five minutes of rest in a supine position ${ }^{8}$.

\section{Ambulatory blood pressure monitoring}

Twenty-four-hour ambulatory blood pressure monitoring was performed by a noninvasive automated system using the oscillometric method (Mobil-o-Graph, IEM GmbH, Stolberg, Germany). On the day of assessment the participants were asked to conduct their usual activities as much as possible, but to refrain from physical exercise and avoid excessive movement of their nondominant arm during measurements. Blood pressure and heart rate were measured every 20 minutes during the daytime (between 08.00 a.m. and 24.00 p.m.) and every 30 minutes during nighttime (between 24.00 p.m. and 08.00 a.m.) More than $80 \%$ successful readings were needed to consider a test adequate for subsequent analysis. The ambulatory blood pressure monitoring was undertaken calculating the standard deviation (SD) of systolic blood pressure for 24 hours. The SD for 24-hour systolic blood pressure was defined as blood pressure variability ${ }^{9}$. Blood pressure was measured in units of $\mathrm{mmHg}(1 \mathrm{mmHg}=0.133 \mathrm{kPa})$.

\section{Biochemical analysis}

Blood samples of the MS patients and control group were collected in vacuum tubes. All venous blood samples were centrifuged at $3000 \mathrm{rpm}$ for 10 minutes, frozen at $-80^{\circ} \mathrm{C}$. Serum 25(OH)vitamin D, VDR and VDBP concentrations were measured using commercial ELISA kits (Elabscience Bioengineering Co., Ltd., Wuhan, China). Serum vitamin D and VDBP concentrations were expressed as $\mathrm{ng} / \mathrm{ml}$ while VDR concentrations were expressed as $\mathrm{pg} / \mathrm{ml}$.

\section{Statistical analysis}

The findings of this study were analyzed using the Statistical Package for Social Sciences for Windows (SPSS v18) software. The conformity of continuous variables to 
normal distribution was tested with the Shapiro-Wilk test. The descriptive statistics of continuous variables were expressed as mean \pm SD or median (min-max) and nominal variables were expressed as number of cases and percentage (\%). The significance of the difference between the groups was evaluated by the Student's t-test and Mann-Whitney U when the number of independent groups was two. Nominal variables were evaluated by Pearson's Chi-Square or Fisher's Chi-Square test. The correlation of variables was analyzed by Spearman's test. A value $\mathrm{p}<0.05$ was considered as the threshold of statistical significance for all tests.

\section{RESULTS}

The demographic characteristics of MS patients and the control group are summarized in Table 1. No statistically significant difference was found between the groups in terms of age, sex and body mass index.
Vitamin D, VDBP, VDR levels and cardiac data of the MS patient group and the control group are shown in Table 2. Serum vitamin D levels were found to be significantly lower in patients with MS than in controls ( $p=0.044)$; however VDR and VDBP levels did not differ significantly between groups. Heart rates, systolic and diastolic blood pressures were similar in both groups and showed no statistically significant differences.

Supine hypertension and orthostatic hypotension were found in patients with MS ( $p=0.023$ and $p=0.023$, respectively). Six of the 26 patients with MS had orthostatic hypotension and six patients had supine hypertension, two patients had both supine hypertension and orthostatic hypotension. Compared with the controls, the systolic blood pressure variability decreased significantly in patients with MS ( $p=0.005$ and $p=0.015)$ (Figure). When the relationships between serum vitamin D, VDR, and VDBP levels and the severity of disease were analyzed, only a negative correlation was found between the VDBP

Table 1. The demographic features of the control and multiple sclerosis patient groups.

\begin{tabular}{lccc}
\hline Variable & Controls $(n=24)$ & Patients $(n=26)$ & p-value \\
\hline Age $[$ mean \pm SD] & $32.20 \pm 4.91$ & $35.57 \pm 6.12$ & 0.140 \\
Sex $[n(\%)]$ & & & 0.963 \\
$\quad$ Male & $10(41.7)$ & $11(42.3)$ & $15(57.7)$ \\
$\quad$ Female & $14(58.3)$ & $25.74 \pm 4.21$ & 0.386 \\
BMI $\left(\mathrm{kg} / \mathrm{m}^{2}\right)[$ mean \pm SD] & $24.79 \pm 3.37$ & $8.19 \pm 5.51$ & $2.26 \pm 1.079$ \\
Disease duration $[$ years \pm SD] & - & $6.62 \pm 7.26$ & \\
EDSS score & - & $19 / 26$ & $7 / 26$ \\
Total number of attacks & - & & \\
Treatment & & &
\end{tabular}

BMI: body mass index; EDSS: Expanded Disability Status Scale; IMT: immunomodulatory therapy (interferon beta-1a, interferon beta-1 b or glatiramer acetate); SD: standard deviation.

Table 2. The level of vitamin D, vitamin D binding protein, vitamin D receptor and cardiac data in multiple sclerosis patients and the control group.

\begin{tabular}{|c|c|c|c|}
\hline Variable & Control $(n=24)$ & MS $(n=26)$ & p-value \\
\hline Vitamin D (ng/ml) & $35.25(10-45.28)$ & $24.98(9.74-47.94)$ & $0.044^{\star}$ \\
\hline $\operatorname{VDBP}(\mathrm{ng} / \mathrm{ml})$ & $41.71 \pm 5.55$ & $43.06 \pm 4$ & 0.326 \\
\hline $\operatorname{VDR}(\mathrm{pg} / \mathrm{ml})$ & 71.66 (47.19-146.88) & 78.35 (48.35-116.62) & 0.431 \\
\hline Heart rate (min) & $74.67 \pm 8.14$ & $76.38 \pm 7.83$ & 0.451 \\
\hline Systolic BP (mm Hg) & $112.16 \pm 9.08$ & $114.15 \pm 8.62$ & 0.431 \\
\hline Diastolic BP (mm Hg) & $70.25 \pm 7.96$ & $72.76 \pm 7.89$ & 0.267 \\
\hline 24-hour systolic BPV & $12.71 \pm 3.57$ & $10.21 \pm 2.35$ & $0.005^{\star}$ \\
\hline Orthostatic hypotension & $0 / 24$ & $6 / 26$ & $0.023^{*}$ \\
\hline Supine hypertension & $0 / 24$ & $6 / 26$ & $0.023^{*}$ \\
\hline
\end{tabular}

VDBP: vitamin D binding protein; VDR: vitamin D receptor; BP: systolic blood pressure; BPV: blood pressure variability. ${ }^{\star}$ All comparisons were considered statistically significant at $p<0.05$ 
and the EDSS ( $\mathrm{p}=0.039, \mathrm{r}=-0.406)$. Orthostatic hypotension and vitamin D related parameters, supine hypertension and vitamin D related parameters, 24 hour systolic blood pressure variability and vitamin D parameters were all analyzed separately. There were no statistically significant correlations (Table 3).

\section{DISCUSSION}

We had several important findings in this study. Firstly, mean serum vitamin D levels were found to be significantly lower in patients with MS than in controls; however, there were no significant differences in VDR and VDBP levels between the groups. Secondly, there was a negative correlation between the VDBP and the EDSS in patients with MS. Thirdly, patients with MS were found to have supine hypertension and orthostatic hypotension, whereas the controls did not. Finally the 24-hour systolic blood pressure variability

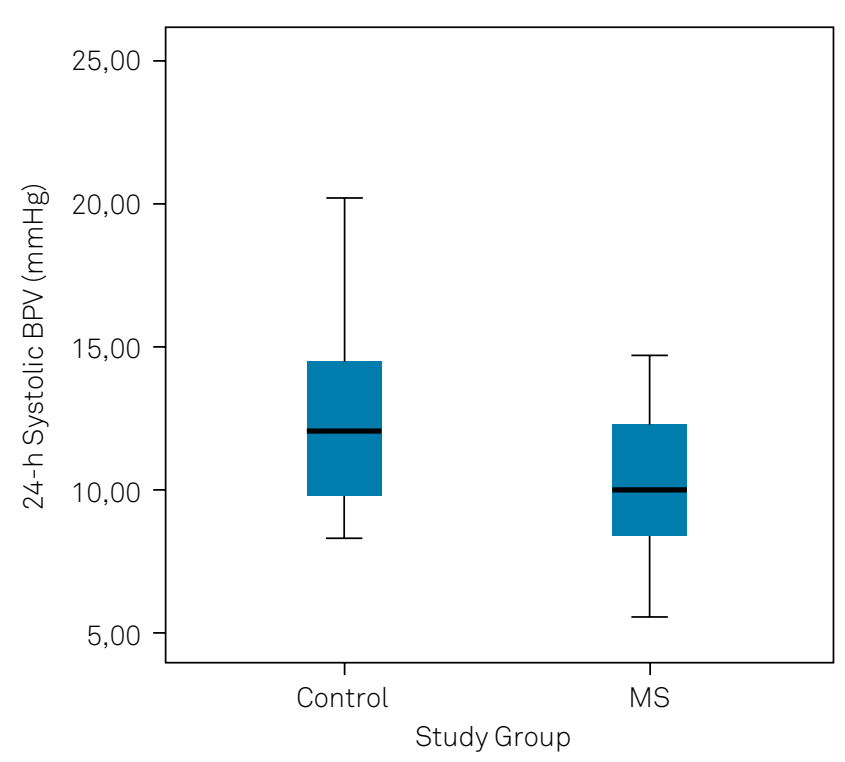

decreased significantly in patients with MS compared with the control group.

Vitamin D [25(OH)D] is a steroid hormone with multisystem regulatory effects and binds to the intracellular receptor. It regulates the expression of numerous different genes involved in the differentiation, activation, and proliferation of many cell types ${ }^{10}$. The active form of vitamin $\mathrm{D}$ can inhibit the expression of IL-2 and INF- $y$, modulate differentiation of Th17 cells, and also has a role in the balance of Th17/T regulatory cells ${ }^{11,12}$. In epidemiological studies, its deficiency was found to be associated with various diseases such as cancer, autoimmune and cardiovascular diseases ${ }^{13,14,15}$. In one study, it was suggested that reduced levels of vitamin D were associated with a greater risk of MS, and serum levels of vitamin $\mathrm{D}$ have been found to be lower in patients with MS than in controls $^{16}$. An inverse relationship has been found between exposure to sunlight or serum vitamin D levels and the prevalence of $\mathrm{MS}^{17}$. Rhead et al. asserted that a low serum $25(\mathrm{OH})$ $\mathrm{D}$ concentration was a cause of MS, regardless of other risk factors ${ }^{18}$. We found lower vitamin D levels in patients with MS than in healthy controls in accordance with the majority of the literature.

Vitamin D binding protein is a carrier protein of vitamin D metabolites with roles in the regulation of vitamin D, the organism's actin scavenging and immunomodulation. In our study, the serum levels of VDBP showed no significant difference between MS patients and the control group. A similar pattern of results was presented by Behrens et al. ${ }^{19}$, who reported no significant differences in the levels of VDBP between clinically isolated syndrome patients (in remission) and their control group. Smolders et al. ${ }^{20}$ found no difference in the level of VDBP in patients with RRMS (in relapse and remission phases). Likewise, in a study by Niino et al. ${ }^{21}$, no difference in patients with RRMS (in the remission phase) and secondary progressive MS was found. On the other hand, the mean VDBP level was found to be higher in patients with RRMS (in the remission phase) in another study ${ }^{22}$.

Figure. 24-hour systolic blood pressure variability values.

Table 3. The correlations of the level of vitamin D, VDBP and VDR with disease characteristics and cardiac autonomic dysfunction findings in patients with multiple sclerosis.

\begin{tabular}{|c|c|c|c|c|c|c|}
\hline \multirow{2}{*}{ Variable } & \multicolumn{2}{|c|}{ Vitamin D } & \multicolumn{2}{|c|}{ VDBP } & \multicolumn{2}{|c|}{ VDR } \\
\hline & $\mathrm{p}$ & rho & $\mathrm{p}$ & rho & $\mathrm{p}$ & rho \\
\hline Total number of attacks & 0.833 & -0.044 & 0.903 & 0.025 & 0.464 & 0.150 \\
\hline EDSS score & 0.229 & -0.244 & 0.039 & -0.406 & 0.500 & 0.138 \\
\hline Duration of the disease & 0.379 & -0.180 & 0.467 & 0.149 & 0.355 & 0.189 \\
\hline Supine hypertension & 0.488 & 0.100 & 0.242 & 0.169 & 0.213 & 0.179 \\
\hline Orthostatic hypotension & 0.517 & 0.094 & 0.617 & 0.073 & 0.769 & 0.043 \\
\hline 24-hour systolic BPV & 0.110 & 0.229 & 0.224 & -0.175 & 0.705 & 0.055 \\
\hline
\end{tabular}


We found an inverse correlation between the levels of VDBP and the EDSS in our study, contrary to a previous study in which no association was found between the disability status of the disease, measured by the EDSS, and $\mathrm{VDBP}^{21}$. In the study by Delanghe et al. ${ }^{23}$, it was asserted that the variation in VDBP genotype may affect the MS risk independently of vitamin D. When all opinions are considered, VDBP may have a complex role in the pathogenesis of MS. It is known that VDBP is a precursor of the macrophage-activating factor and cofactor for C5a-mediated chemotaxis $^{24}$. In our study, as the severity of the disease increased, the level of VDBP decreased. This finding may have been a result of intense inflammation or a protective and limiting response of the organism against inflammation. Smolders et al. ${ }^{20}$ also determined that VDBP was not correlated with either vitamin $\mathrm{D}$ or with the active form of vitamin $\mathrm{D}[1,25(\mathrm{OH}) \mathrm{D}]$ in MS participants.

Vitamin D shows most of its effects on the organism via the VDR. The VDR is expressed in neuronal cells, glial cells and immune system cells such as monocytes, macrophages, activated $\mathrm{T}$ and $\mathrm{B}$ cells. It regulates the expression of genes involved in organ development, cell cycle control, calcium and phosphate homeostasis in bone metabolism, and xenobiotic detoxification ${ }^{25}$. The association of VDR polymorphism with MS has been investigated in many studies, yielding controversial results. A recent review found no association between VDR polymorphism and the risk of $\mathrm{MS}^{26}$. Although the level of vitamin $\mathrm{D}$ was lower in MS patients, no difference was found in the serum level of VDR and VDBP of the two groups. These findings may show that vitamin $\mathrm{D}$ is a parameter independent of VDBP and VDR and genetic susceptibility is important in MS disease.

Autonomic dysfunction is common in patients with MS and affects the quality of life of patients ${ }^{27}$. Autonomic dysfunction affects the bowel, bladder and sexual functions as well as the cardiovascular system. There is evidence that the sympathetic and parasympathetic systems are affected in patients with $\mathrm{MS}^{28}$. A recent review has indicated that the risk of cardiovascular disease increased during the first five years after the diagnosis of $\mathrm{MS}^{29}$. While orthostatic hypotension is a known finding of autonomic dysfunction in patients with MS, to the best our knowledge the supine hypertension has not been previously noted. Orthostatic hypotension and supine hypertension are findings of cardiovascular autonomic failure. Supine hypertension may present in patients with orthostatic hypotension, possibly an outcome of the same underlying pathologic process. These patients are devoid of the buffering mechanisms of normal blood pressure ${ }^{30}$.

Blood pressure variability is defined as the standard deviation of blood pressure and may demonstrate blood pressure fluctuations over a particular period of time. The known underlying mechanisms of blood pressure variability are limited. Autonomic dysfunction and arterial stiffness have been reported to be the two main reasons for increased blood pressure variability ${ }^{31,32}$. We found that the 24-hour systolic blood pressure variability decreased in patients with MS in our study. One possible explanation for decreased systolic blood pressure variability in these patients may have been dysmodulation of the sympathetic and parasympathetic nervous systems, the influence of neural control on blood pressure). Another possibility is that decreased sympathetic system activation in patients with MS may have led to such a result. Shirbani et al. ${ }^{33}$ studied systolic blood pressure variability in patients with MS and found reduced sympathetic function. In another study, it was suggested that increases in short-term blood pressure variability may reflect alterations in regulatory mechanisms such as an enhanced sympathetic drive or impaired baroreflex function ${ }^{34}$.

It has been suggested that vitamin $\mathrm{D}$ deficiency may contribute to the dysfunction of autonomic pathways in $\mathrm{MS}^{35}$. In a rat study conducted by Atchison et al., it was shown that sympathetic activity and $\beta$-adrenergic receptor stimulation were increased by $1,25(\mathrm{OH})$-vitamin $\mathrm{D}^{36}$. An association between low 25(OH)-vitamin D levels and depressed baseline cardiac autonomic activity was reported in another study ${ }^{37}$. Oral administration of 1,25(OH)-vitamin $\mathrm{D}$ to diabetic rats caused an increase in expression and binding capacity of cholinergic receptors in the brainstem $^{38}$. Contrary to the evidence that there is an interaction between vitamin $\mathrm{D}$ and autonomic nervous system dysfunction reported in the literature, we did not find any correlation between cardiac dysautonomia and serum vitamin D, VDBP, or VDR levels in patients with MS. One possibility for this was that we had conducted the study with a relatively small number of participants. Further studies are required with a larger patient population to establish interactions between vitamin $\mathrm{D}$ and the autonomic nervous system.

Our study has several limitations, primarily due to the small sample size. Secondly, some of the patients with MS were under the effects of immunomodulatory treatment at the time of examination. An investigation of serum vitamin D, VDBP and VDR levels and autonomic dysfunction in untreated patients with MS will pave the way for future studies. Another limitation was the inclusion of patients only in the remission phase. In this context, patients with primary or secondary progressive MS and RRMS in the relapse phase may yield different results.

In summary, to our knowledge, this is the first report to evaluate the interaction between vitamin $\mathrm{D}$ and cardiac dysautonomia in MS patients. There was no relationship between cardiac autonomic dysfunction and vitamin D-related parameters (vitamin D, VDBP, VDR). Further work is certainly required to clarify the relationship between vitamin $\mathrm{D}$ and the autonomic nervous system. 


\section{References}

1. Kępczyńska K, Zajda M, Lewandowski Z, Przedlacki J, ZakrzewskaPniewska B. Bone metabolism and vitamin D status in patients with multiple sclerosis. Neurol Neurochir Pol. 2016 Jul-Aug;50(4):251-7. https://doi.org/10.1016/j.pjnns.2016.04.010

2. Wei R, Christakos S. Mechanisms underlying the regulation of innate and adaptive immunity by vitamin D. Nutrients. $2015 \mathrm{Sep} ; 7(10): 8251-$ 60. https://doi.org/10.3390/nu7105392

3. Kamen DL, Tangpricha V. Vitamin D and molecular actions on the immune system: modulation of innate and autoimmunity. J Mol Med (Berl). 2010 May;88(5):441-50. https://doi.org/10.1007/s00109-010-0590-9

4. Wadhwania R. Is Vitamin D deficiency implicated in autonomic dysfunction? J Pediatr Neurosci. 2017 Apr-Jun;12(2):119-23. https://doi.org/10.4103/jpn.JPN_1_17

5. Sternberg Z. Cardiovascular autonomic dysfunction: link between multiple sclerosis osteoporosis and neurodegeneration. Neuromolecular Med. 2018 Mar;20(1):37-53. https://doi.org/10.1007/s12017-018-8481-2

6. Polman CH, Reingold SC, Banwell B, Clanet M, Cohen JA, Filippi $\mathrm{M}$, et al. Diagnostic criteria for multiple sclerosis: 2010 revisions to the McDonald criteria. Ann Neurol. 2011 Feb;69(2):292-302. https://doi.org/10.1002/ana.22366

7. Joseph A, Wanono R, Flamant M, Vidal-Petiot E. Orthostatic hypotension: areview. Nephrol Ther. 2017 Apr;13 Suppl 1:S55-67. https://doi.org/10.1016/j.nephro.2017.01.003

8. Fanciulli A, Jordan J, Biaggioni I, Calandra-Buonaura G, Cheshire WP, Cortelli P, et al. Consensus statement on the definition of neurogenic supine hypertension in cardiovascular autonomic failure by the American Autonomic Society (AAS) and the European Federation of Autonomic Societies (EFAS) : endorsed by the European Academy of Neurology (EAN) and the European Society of Hypertension (ESH). Clin Auton Res. 2018 Aug;28(4):355-62. https://doi.org/10.1007/s10286-018-0529-8

9. Wang X, Wang F, Chen M, Wang X, Zheng J, Qin A. Twenty-fourhour systolic blood pressure variability and renal function decline in elderly male hypertensive patients with wellcontrolled blood pressure. Clin Interv Aging. 2018 Apr;13:533-40. https://doi.org/10.2147/CIA.S161752

10. Colotta F, Jansson B, Bonelli F. Modulation of inflammatory and immune responses by vitamin D.J Autoimmun. 2017 Dec;85:78-97. https://doi.org/10.1016/j.jaut.2017.07.007

11. Colin EM, Asmawidjaja PS, Hamburg JP, Mus AM, Driel M, Hazes JM, et al. 1,25-dihydroxyvitamin D3 modulates Th17 polarization and interleukin-22 expression by memory T cells from patients with early rheumatoid arthritis. Arthritis Rheum. 2010 Jan;62(1):132-42. https://doi.org/10.1002/art.25043

12. Joshi S, Pantalena LC, Liu XK, Gaffen SL, Liu H, Rohowsky-Kochan C, et al. 1,25-dihydroxyvitamin D(3) ameliorates Th17 autoimmunity via transcriptional modulation of interleukin-17A. Mol Cell Biol. 2011 Sep;31(17):3653-69. https://doi.org/10.1128/MCB.05020-11

13. McCullough ML, Zoltick ES, Weinstein SJ, Fedirko V, Wang M, Cook NR2, et a. Circulating Vitamin D and colorectal cancer risk: an international pooling project of 17 cohorts. J Natl Cancer Inst. 2019 Feb 1;111(2):158-169. https://doi.org/10.1093/jnci/djy087

14. Del Pinto R, Pietropaoli D, Chandar AK, Ferri C, Cominelli F. Association between inflammatory bowel disease and vitamin $D$ deficiency: a systematic review and metaanalysis. Inflamm Bowel Dis. 2015 Nov;21(11):2708-17. https://doi.org/10.1097/MIB.0000000000000546

15. Robinson-Cohen C, Hoofnagle AN, IX JH, Sachs MC, Tracy RP, Siscovick DS, et al. Racial differences in the association of serum 25-hydroxyvitamin D concentration with coronary heart disease events. JAMA. 2013 Jul;310(2):179-88. https://doi.org/10.1001/jama.2013.7228

16. Mansouri B, Asadollahi S, Heidari K, Fakhri M, Assarzadegan F, Nazari M, et al. Risk factors for increased multiple sclerosis susceptibility in the Iranian population. J Clin Neurosci. 2014 Dec;21(12):2207-11. https://doi.org/10.1016/j.jocn.2014.04.020

17. Bjørnevik K, Riise T, Casetta I, Drulovic J, Granieri E, Holmøy T, et al. Sun exposure and multiple sclerosis risk in Norway and Italy: the EnvIMS study. Mult Scler. 2014 Jul;20(8):1042-9. https://doi.org/10.1177/1352458513513968

18. Rhead B, Bäärnhielm M, Gianfrancesco M, Mok A, Shao X, Quach $\mathrm{H}$, et al. Mendelian randomization shows a causal effect of low vitamin D on multiple sclerosis risk. Neurol Genet. 2016 Sep;2(5):e97. https://doi.org/10.1212/NXG.0000000000000097

19. Behrens JR, Rasche L, Gieß RM, Pfuhl C, Wakonig K, Freitag E, et al. Low 25-hydroxyvitamin D, but not the bioavailable fraction of 25-hydroxyvitamin D, is a risk factor for multiple sclerosis. Eur $\mathrm{J}$ Neurol. 2016 Jan;23(1):62-7. https://doi.org/10.1111/ene.12788

20. Smolders J, Peelen E, Thewissen M, Menheere P, Damoiseaux J, Hupperts R. Circulating vitamin D binding protein levels are not associated with relapses or with vitamin D status in multiple sclerosis. Mult Scler. 2014 Apr;20(4):433-7. https://doi.org/10.1177/1352458513500552

21. Niino M, Sato S, Fukazawa T, Masaki K, Miyazaki Y, Matsuse D, et al. Decreased serum vitamin D levels in Japanese patients with multiple sclerosis. J Neuroimmunol. 2015 Feb;279:40-5. https://doi.org/10.1016/j.jneuroim.2015.01.007

22. Rinaldi AO, Sanseverino I, Purificato C, Cortese A, Mechelli R, Francisci S, et al. Increased circulating levels of vitamin $D$ binding protein in MS patients. Toxins (Basel). 2015 Jan;7(1):129-37. https://doi.org/10.3390/toxins7010129

23. Delanghe JR, Speeckaert R, Speeckaert MM. Behind the scenes of vitamin $\mathrm{D}$ binding protein: more than vitamin $\mathrm{D}$ binding. Best Pract Res Clin Endocrinol Metab. 2015 Oct;29(5):773-86. https://doi.org/10.1016/j.beem.2015.06.006

24. Gauzzi MC. Vitamin D-binding protein and multiple sclerosis: Evidence, controversies, and needs. Mult Scler. 2018 Oct;24(12):1526-35. https://doi.org/10.1177/1352458518792433

25. Haussler MR, Whitfield GK, Kaneko I, Haussler CA, Hsieh D, Hsieh JC, et al. Molecular mechanisms of vitamin D action. Calcif Tissue Int. 2013 Feb;92(2):77-98. https://doi.org/10.1007/s00223-012-9619-0

26. Zhang YJ, Zhang L, Chen SY, Yang GJ, Huang XL, Duan Y, et al. Association between VDR polymorphisms and multiple sclerosis: systematic review and updated meta-analysis of case-control studies. Neurol Sci. 2018 Feb;39(2):225-34. https://doi.org/10.1007/s10072-017-3175-3

27. Vieira B, Costa A, Videira G, Sá MJ, Abreu P. Prevalence of autonomic dysfunction in patients with multiple sclerosis. Acta Med Port. 2015 Jan-Feb;28(1):51-5. https://doi.org/10.20344/amp.5562

28. Racosta JM, Sposato LA, Morrow SA, Cipriano L, Kimpinski K, Kremenchutzky M. Cardiovascular autonomic dysfunction in multiple sclerosis: a meta-analysis. Mult Scler Relat Disord. 2015 Mar;4(2):104-11. https://doi.org/10.1016/j.msard.2015.02.002

29. Christiansen CF. Risk of vascular disease in patients with multiple sclerosis: a review. Neurol Res. 2012 Oct;34(8):746-53. https://doi.org/10.1179/1743132812Y.0000000051

30. Gibbons $\mathrm{CH}$, Schmidt P, Biaggioni I, Frazier-Mills C, Freeman R, Isaacson $\mathrm{S}$, et al. The recommendations of a consensus panel for the screening, diagnosis, and treatment of neurogenic orthostatic hypotension and associated supine hypertension.J Neurol. 2017 Aug;264(8):1567-82. https://doi.org/10.1007/s00415-016-8375-x 
31. Sueta D, Koibuchi N, Hasegawa Y, Toyama K, Uekawa K, Katayama T, et al. Blood pressure variability, impaired autonomic function and vascular senescence in aged spontaneously hypertensive rats are ameliorated by angiotensin blockade. Atherosclerosis. 2014 Sep;236(1):101-7. https://doi.org/10.1016/j.atherosclerosis.2014.06.016

32. Schillaci G, Bilo G, Pucci G, Laurent S, Macquin-Mavier I, Boutouyrie $P$, et al. Relationship between short-term blood pressure variability and large-artery stiffness in human hypertension: findings from 2 large databases. Hypertension. 2012 Aug;60(2):369-77. https://doi.org/10.1161/HYPERTENSIONAHA.112.197491

33. Shirbani F, Barin E, Lee YC, Ng K, Parratt JD, Butlin M, et al. Characterisation of cardiac autonomic function in multiple sclerosis based on spontaneous changes of heart rate and blood pressure. Mult Scler Relat Disord. 2018 May;22:120-7. https://doi.org/10.1016/j.msard.2018.03.018

34. Parati G, Ochoa JE, Lombardi C, Bilo G. Blood pressure variability: assessment, predictive value, and potential as a therapeutic target. Curr Hypertens Rep. 2015 Apr;17(4):537. https://doi.org/10.1007/s11906-015-0537-1

35. Racosta JM, Kimpinski K, Morrow SA, Kremenchutzky M. Autonomic dysfunction in multiple sclerosis. Auton Neurosci. 2015 Dec;193:1-6. https://doi.org/10.1016/j.autneu.2015.06.001

36. Atchison DK, Harding P, Beierwaltes WH. Vitamin D increases plasma renin activity independently of plasma $\mathrm{Ca} 2+$ via hypovolemia and $\beta$-adrenergic activity. Am J Physiol Renal Physiol. 2013 Oct 15;305(8):F1109-17. https://doi.org/10.1152/ajprenal.00010.2013

37. Mann MC, Exner DV, Hemmelgarn BR, Sola DY, Turin TC, Ellis L, et al. Vitamin D levels are associated with cardiac autonomic activity in healthy humans. Nutrients. 2013 Jun;5(6):2114-27. https://doi.org/10.3390/nu5062114

38. Peeyush Kumar T, Paul J, Antony S, Paulose CS. Expression of cholinergic, insulin, vitamin D receptors and GLUT 3 in the brainstem of streptozotocin induced diabetic rats: effect of treatment with vitamin $D_{3}$. Neurochem Res. 2011 Nov;36(11):2116-26. https://doi.org/10.1007/s11064-011-0536-9

In the manuscript "Vitamin D, vitamin D binding protein, vitamin D receptor levels and cardiac dysautonomia in patients with multiple sclerosis: a cross-sectional study", DOI: 10.1590/0004-282x20190182, published in the Arq Neuropsiquiatr 2019;77(12):848-54. Epub Jan 10, 2020, on page 848.

\section{Where it reads:}

${ }^{1}$ Bozok University, Department of Neurology, Yozgat, Turkey;

\section{It should read:}

${ }^{1}$ Bozok University, Department of Cardiology, Yozgat, Turkey; 